\title{
Antioxidant and Antimicrobial Activity of Basil, Thyme and Tarragon Used in Meat Products
}

\author{
Elisaveta Sandulachi ${ }^{1}$, Artur Macari1 ${ }^{1}$ Aliona Ghendov-Mosanu ${ }^{*}{ }^{\circledR}$, Daniela Cojocari ${ }^{*}$, \\ Rodica Sturza ${ }^{3}$
}

\author{
${ }^{1}$ Department of Food Technology, Technical University of Moldova, Chisinau, Republic of Moldova \\ ${ }^{2}$ Department of Preventive Medicine, "Nicolae Testemitanu" State University of Medicine and Pharmacy, Chisinau, Republic of \\ Moldova \\ ${ }^{3}$ Department of Oenology and Chemistry, Technical University of Moldova, Chisinau, Republic of Moldova \\ Email: *aliona.mosanu@tpa.utm.md, ^daniela.cojocari@usmf.md
}

How to cite this paper: Sandulachi, E., Macari, A., Ghendov-Mosanu, A., Cojocari, D. and Sturza, R. (2021) Antioxidant and Antimicrobial Activity of Basil, Thyme and Tarragon Used in Meat Products. Advances in Microbiology, 11, 591-606.

https://doi.org/10.4236/aim.2021.1111043

Received: October 2, 2021

Accepted: November 2, 2021

Published: November 5, 2021

Copyright (c) 2021 by author(s) and Scientific Research Publishing Inc. This work is licensed under the Creative Commons Attribution International License (CC BY 4.0)

http://creativecommons.org/licenses/by/4.0/

(c) (i) Open Access

\begin{abstract}
Currently, the food industry, including the meat industry, is paying close attention to the use of natural additives as preservatives. From ancient times, the plants are used to treat various diseases, to produce perfumes and as ingredients to improve the taste in food. This paper presents a bibliographic and experimental study of the antioxidant and microbial properties of basil, thyme and tarragon. International scientific papers on the use of these plants in the food industry, including the meat industry, are targeted. The role of basil, thyme and tarragon in the manufacture of functional and stable products in storage is mentioned. Percentage decrease in Salmonella Abony growth under the influence of basil constituted $84.4 \%$, thyme $61.6 \%$ and tarragon $76.8 \%$ after 48 hours of action and respectively $97.2 \%, 90.2 \%$ and $95.3 \%$ after 72 hours of action. The interdependence between the percentage reduction of S. Abony infestation and the concentration of basil, mushrooms and tarragon was respectively: basil $\left(R^{2}=0.7725 \ldots 0.7916\right)$, thyme $\left(R^{2}=0.7733 \ldots 0.7768\right)$, tarragon $\left(R^{2}=0.7689 \ldots 0.8137\right)$.
\end{abstract}

\section{Keywords}

Basil, Tarragon, Thyme, Antimicrobial Activity, Antioxidant Activity, Meat Products

\section{Introduction}

The European Commission has accepted various components of essential oil (EO) as food-friendly and safe. The FDA classifies these substances as GRAS 
(generally recognized as safe). This category includes thyme, cloves, cinnamon, oregano, mustard, nutmeg and basil [1] [2] [3] [4].

The use of new plant oil extraction technologies makes it possible to use them successfully in the manufacture of supplements and new products with high biological value [5] [6]. The authors of the studies [7] and [8] mention the great biological and structural diversity of the compounds found in different plants, noting their antifungal, antibacterial and antiparasitic properties. The antioxidant properties of thyme have been reported in studies [9] [10] [11], mentioning its use in the stability of meat lipids. Also of interest are the results of the study of thyme used for pork, reported by Tanabe $\mathrm{H}$, et al. [12]; and for beef reported by Medina et al. [13].

The data reported in studies [13] [14] [15] [16] [17], regarding the antimicrobial properties of herbs and spices, would be of interest to food industry specialists.

Natural antioxidants are increasingly mentioned as an object of study in research worldwide [18] [19] [20] the most important being tocopherols, flavonoids and phenolic acids. Most often these substances are investigated as a potential to prevent or delay the oxidation of lipids [21] [22]. The content and activity of antioxidants in plants depends on several factors: climate genotype, temperature, light, soil type and other conditions (processing, storage after harvest), etc. [23].

\section{General Characteristics of Thyme, Basil and Tarragon}

\section{Antioxidant and antimicrobial activity of thyme.}

The role of thyme in increasing stability and reducing lipid oxidation during food storage is reported in papers [24] [25] [26]. The oxidative inhibitory capacity of thyme extracts is mainly due to the content of phenolic compounds [27]. The results presented by the study authors [28] [29] suggest the idea that essential oils from different Thymus species, having antimicrobial properties, can be used in the food industry.

Tepe et al. [30] studied the antioxidant properties of two varieties of Thymus sipyleus, reporting different constituents in their essential oil. Dorman et al. [31] established that there is no direct relationship between the antioxidant efficacy of an extract and its total phenolic compound content. Another study by Sun et al. [32] established that there is an apparent relationship between the antioxidant potential of Thymus zygis extracts and the total phenols they contain. Thyme phenols are characterized by redox properties and neutralize free radicals [1] [33]. Essential oils rich in phenolic compounds have antimicrobial properties [34]. Factors that influence the microbial activity of thyme oils are: low temperatures, anaerobic conditions and low $\mathrm{pH}$. Gram-positive bacteria appear to be less sensitive to thyme action than gram-negative bacteria [2] [35]. Evans and Martin [36] reported antimicrobial activity of thyme on Salmonella, Staphylococcus, Escherichia coli, Klebsiella, Pseudomonas and Enterococcus. 


\section{Antioxidant and antimicrobial activity of basil.}

Sweet basil (Ocimum basilicum L.) has relevant antioxidant and antimicrobial properties [37] [38] [39]. The authors of the studies [40] [41] report the antibacterial properties (Gram-negative and Gram-positive bacteria, yeast, and mold). Another study by Zheljazkov et al. includes oil content, composition and bioactivity of Ocimum basilicum L. [42]. Rezzoug M. et al. [43] also mentioned the antioxidant and antimicrobial activity of plants, and the possibility of using them as natural preservatives is discussed by Tiwari B.K et al. [44]. Also relevant are the studies: [45] [46], which report moderate antioxidant activity and strong antifungal and antibacterial activity of basil extracts, [47] the use of basil oil for the production of organic packaging is mentioned in the study, [48] cure fungal infections and stop the growth of Aspergillus flavus and aflatoxin B1 production. In their research, Gülten Ökmen et al. [49] noted that the antioxidant and antimicrobial properties of Ocimum basilicum L. depend on the solvent (methanol or water), a high antioxidant activity was obtained from water extracts (72\%).

\section{Antioxidant and antimicrobial activity of tarragon}

Lipid oxidation [50] [51] and contamination with microorganisms diminish the quality and safety of meat products [52]. The results of the study by Chaleshtori et al. [53] in meat products have shown that Tarragon (Artemisia dracunculus L.) oil has antibacterial and flavoring properties. Behbahani et al. [54] reported the chemical composition of Artemisia dracunculusas L. essential oil, mentioning in detail the content of antioxidants, as well as antimicrobial activity against fungi with an average inhibitory area of $14.70 \mathrm{~mm}$. The antibacterial potential of Artemisia dracunculusas L. plant oil has been reported in several studies: depending on the method of obtaining the oil [55] [56], the method of testing bacteriostatic and bactericidal activities [57], the minimum inhibitory concentration (MIC) and the minimum bactericidal concentration (MBC) [58] [59].

The antibacterial activity of an aqueous infusion of tarragon against Grampositive bacteria and Gram-negative bacteria was reported in the study by Majdan et al. [60].

Currently, the antioxidant and antimicrobial properties of thyme, basil and tarragon are being studied by many scientists. Table 1 and Table 2 are presented some results obtained at international level.

\section{Materials and Methods}

\section{Materials.}

Sausages obtained by the classical method (control test) and with the addition of lyophilized hydroalcoholic extracts $60 \%(\mathrm{v} / \mathrm{v})$ of basil, thyme, and tarragon in concentrations of $0.1 \% ; 0.2 \%$ and $0.3 \%$. Sausages previously infected with reference strains: Salmonella Abony were investigated for the growth rate of pathogenic microorganisms within 24,48 and 72 hours. The concentration of bacterial cell suspensions was $2 \times 10^{5} \mathrm{CFU} / \mathrm{mL}$. 
Table 1. The components that exhibit antibacterial properties.

\begin{tabular}{|c|c|c|c|}
\hline $\begin{array}{l}\text { Essential } \\
\text { Oil }\end{array}$ & Plant source & Major components & $\begin{array}{l}\text { Bibliographic } \\
\text { sources }\end{array}$ \\
\hline Thyme & Thymus vulgaris & Thymol, carvacrol, $\gamma$-terpinene, $p$-cymene, linalool. & [61]-[69] \\
\hline Thyme & Thymus vulgaris & $\begin{array}{c}\text { 1,8-cineol (14.26\%), } \gamma \text {-terpinen (12.06\%), } p \text {-cimen }(10.50 \%) \\
\text { and } \alpha \text {-terpinen }(9.22 \%)\end{array}$ & [70] \\
\hline Thyme sp & & $\begin{array}{l}\alpha \text {-thujene, } \alpha \text {-pinene, } \beta \text {-myrcene, phellandrene, } \\
\alpha \text {-terpinene, } p \text {-cymene, } \gamma \text {-terpinene, } \\
\text { 4-terpineol, carvacrol, } \beta \text {-bisabolene, carvone. }\end{array}$ & {$[71][72]$} \\
\hline Thyme sp & & $\begin{array}{l}\text { Thyme contains monoterpene phenols, including } \\
\text { carvacrol (isopropyl- } o \text {-cresol; } 0.4 \%-20.6 \%) \text {, thymol } \\
\text { (2-isopropyl-5-methylphenol or isopropyl- } m \text {-cresol) } \\
\text { and } p \text {-cymene, and other monoterpenes, such as } \alpha \text {-pinene, } \\
\text { 1,8-cineol, camphor, linalool and borneol. }\end{array}$ & [1] [3] \\
\hline Basil & Ocimum basilicum $\mathrm{L}$. & $\begin{array}{l}\text { Geraniol, } p \text {-allylanisole, } 1,8 \text {-cineole, } \\
\text { trans- } \alpha \text {-bergamotene and neryl acetate. }\end{array}$ & {$[73][74]$} \\
\hline Basil & Ocimum basilicum L. & $\begin{array}{l}\text { Total amount of phenols. High activity of the extract } \\
\text { was also demonstrated in the DPPH and ABTS tests. }\end{array}$ & {$[60]$} \\
\hline Basil & Ocimum basilicum $\mathrm{L}$. & Flavonoids and phenolic acids. & [58] \\
\hline Basil & Ocimum basilicum $\mathrm{L}$. & $\begin{array}{l}\text { Methyl chavicol, gitoxigenin, trimethoquinol, } \beta \text {-guaiene, } \\
\text { aciphyllene, alizarin, naphthaline, } \\
(-) \text {-caryophyllene, and mequinol }\end{array}$ & {$[75][76]$} \\
\hline Basil & Ocimum basilicum $\mathrm{L}$. & $\begin{array}{l}\text { The } 52 \text { compounds were identified: linalool, } 1,8 \text {-cineole, } \\
\text { (Z)-isoeugenol, } 1 \text {-epi-cubenol, } \alpha \text {-transbergamotene, and } \\
\text { (Z)-anethol. Further compounds, occurring in amounts } \\
\text { between } 2 \text { and } 3 \% \text {, are trans-muurola- } 4 \text {-(14), 5-diene (2.8\%), } \\
\text { caryophyllene (2.4\%), isobornylacetate }(2.1 \%) \text {, } \\
\text { whereas all the others are present in amounts lower than } 2 \% \text {. }\end{array}$ & {$[77]$} \\
\hline Basil & Ocimum basilicum L. & Estragole, 1, 6-octadien-3-ol, 3,7-dimethyl. & {$[74]$} \\
\hline Basil & Ocimum basilicum L. & $\begin{array}{l}\text { Methyl chavicol, trans-ocimen, } \mathrm{z}-\beta \text {-ocimen, limonene and } \\
\alpha \text {-pinene. Most of the compounds were monoterpene } \\
\text { hydrocarbons and the lowest-sesquiter-feather hydrocarbons. }\end{array}$ & {$[60]$} \\
\hline Tarragon & Artemisia dracunculus L. & $\begin{array}{l}\text { Caffeoylquinic acids, quercetin, isorhamnetin, syringetin, } \\
\text { apigenin, patuletin derivatives, davidigenin, sakuranetin, } \\
\text { four phenolic acid derivatives and one coumarin. }\end{array}$ & {$[60]$} \\
\hline Tarragon & Artemisia dracunculus $\mathrm{L}$. & $\begin{array}{c}\alpha \text {-pinene, } \beta \text {-pinene, } \beta \text {-myrcene, limonene, } \mathrm{z} \text { - } \beta \text {-ocimene, } \\
\text { trans-ocimene, terpinene, linalool, ocimene (allo), } \\
\text { methyl chavicol, geranial iso bornyl acetate eugenol, } \\
\text { iso safrole }(\mathrm{E}), \text { methyl eugenol, valencene, } \\
\beta \text {-sesquiphellandrene cinnamaldehyde, spathulenol. }\end{array}$ & {$[78]$} \\
\hline Tarragon & Artemisia dracunculus L. & $\begin{array}{l}\text { Major phenolic compounds, chlorogenic, syringic, } \\
\text { and caffeic acids, the predominant flavonoid-quercetin. }\end{array}$ & {$[79][80]$} \\
\hline French tarragon & Artemisia dracunculus L. & $\begin{array}{l}\text { Anisaldehyde, paracymene, eugenol, limonene, linalool, } \\
\text { menthol, cis-ocimene, } \alpha \text {-phellandrene, } \alpha \text {-pinene and } \beta \text {-pinene. }\end{array}$ & {$[81]$} \\
\hline
\end{tabular}


Table 2. Antimicrobial activity.

\begin{tabular}{|c|c|c|}
\hline $\begin{array}{l}\text { Essential } \\
\text { Oil }\end{array}$ & Inhibited microorganisms & $\begin{array}{l}\text { Bibliographic } \\
\text { sources }\end{array}$ \\
\hline Thyme & $\begin{array}{c}\text { B. ceruse, E. coli, L. monocytogenes, } \\
\text { S. Typhimurium, S. typhi, S. aureus, Yersinia spp. }\end{array}$ & {$[70]$} \\
\hline Thyme & $\begin{array}{l}\text { Cl. perfringens, Shigella sonnei, } \\
\text { Sarcina lutea, Brochothrix thermosphacta. }\end{array}$ & [73] [82] \\
\hline Thyme & $\begin{array}{c}\text { F. oxysporum, } F \text {. verticillioides, } P \text {. expansum, } \\
\text { P. brevicompactum, A. flavus, } \\
\text { A. fumigatus, Alternaria alternata. }\end{array}$ & {$[83]$} \\
\hline Thyme & $\begin{array}{l}\text { S. aureus, E. coli, } P \text {. aeruginosa as well as against } \\
\text { Streptococcus pyogenes, Corynebacterium, } \\
\text { Salmonella, Bacteroides and Candida albicans. }\end{array}$ & {$[84]$} \\
\hline Thyme sp & S. aureus, E. coli. & {$[72]$} \\
\hline Thyme sp & L. innocua and L. monocytogenes. & {$[84][85]$} \\
\hline Basil & $\begin{array}{l}\text { Gram-positive bacteria and } \\
\text { moderate activity Gram-negative bacteria. }\end{array}$ & [83] \\
\hline Basil & $\begin{array}{l}\text { B. cereus, B. subtilis, B. megaterium, S. aureus, } \\
\text { L. monocytogenes, E. coli, Sh. boydii, Sh. dysenteriae, } \\
\text { V. parahaemolyticus, V. mimicus, and S. typhi. }\end{array}$ & {$[75]$} \\
\hline Basil & $\begin{array}{l}\text { B. thermosphacta 7R1, B. thermosphacta D274, } \\
\text { Carnobacterium maltaromaticum 9P, } \\
\text { Carnobacterium maltaromaticum D1203, E. coli } 32 \text {, } \\
\text { E. faecalis 226, E. faecalis E21, Hafnia alvei 53M, } \\
\text { Listeria innocua 1770, Serratia proteamaculans 20P, } \\
\text { Streptococcus salivarius GM, Staphylococcus } \\
\text { saprophyticus } 3 \mathrm{~S}, \text { Staphylococcus xylosus ES1. }\end{array}$ & [77] \\
\hline Tarragon & $\begin{array}{l}\text { S. aureus ATCC6538, S. epidermidis ATCC14990, } \\
\text { and } S . \text { aureus MRSA } \\
\text { (methicyllin-resistant } S \text {. aureus) ATCC43300. }\end{array}$ & {$[60]$} \\
\hline Tarragon & $\begin{array}{l}\text { S. aureus PTCC (Persian Type Culture Collection) } \\
\text { 1189, Al. faecalis PTCC 1624, Providencia rettgeri } \\
\text { PTCC 1512, Serratia marcescens PTCC 1621, } \\
\text { Sh. dysenteriae PTCC } 1188, \text { L. monocytogenes } \\
\text { PTCC } 1163 \text { and Klebsiella oxytoca } 1402 .\end{array}$ & [78] \\
\hline Tarragon & $\begin{array}{l}\text { E. coli, } P \text {. aeruginosa, } S \text {. aureus, Str, } \\
\text { faecalis and } Y \text {. enterocolitica. }\end{array}$ & {$[80]$} \\
\hline
\end{tabular}

\section{Count bacteria.}

Bacterial growth in the tested sausage samples was assessed by the standard method [86].

Growth rate of bacteria.

The specific growth rates of individual strains were calculated as:

$$
\mu=\frac{\ln X-\ln X_{0}}{\Delta \tau}
$$


where: $X$-the number of bacteria in the end of the exponential growth phase.

$X_{0}$-the number of bacteria in the beginning of the exponential growth phase.

$\Delta \tau$-the time interval between observations.

\section{Statistical analysis.}

The analysis of the variance of the results was performed by applying the Student test and the Microsoft Office Excel 2010 program ( $p$ value $<0.05$ ). All tests were performed in triplicate. The experimental results are expressed as average \pm SD.

\section{Results and Discussions}

The influence of various basil, thyme, and tarragon extracts on the development of Salmonella Abony after 24, 48 and 72 hours was studied, with which the sausage samples were inoculated. The results are presented in Figure 1. The control sample shows a much larger number of colonies of microorganisms compared to the other samples.

The growth rate of Salmonella Abony was calculated, the results are shown in Table 3. After 24 hours the growth rate of bacteria was 0.3 in all samples. Different results were obtained after 48 and 72 hours of incubation at $37^{\circ} \mathrm{C}$. In the control sample the growth rate of Salmonella Abony was 0.18 and respectively 0.12 , in the samples with the addition of basil, thyme, and tarragon the rate for concentration of $0.3 \%$ was $0.14-0.15$ and respectively $0.07-0.09$.

Our experimental results confirm the antimicrobial properties of basil, thyme, and tarragon exposed by other authors presented above. Figure 2 shows the percentage decrease in Salmonella Abony growth under the influence of thyme, basil, and tarragon after 48 and 72 hours.

The most effective in reducing Salmonella Abony was basil, in the samples with an addition of $0.2 \%$, the decrease in bacterial growth was $77.2 \%$, and in

Table 3. Growth rate of Salmonella Abonybacteria on different nutritional substrates.

\begin{tabular}{|c|c|c|c|c|c|c|c|c|}
\hline \multirow{3}{*}{$\begin{array}{l}\text { Name of } \\
\text { the sample }\end{array}$} & \multirow{3}{*}{$\begin{array}{c}\text { Concentration, } \\
\%\end{array}$} & \multicolumn{7}{|c|}{ Incubation time, $h$} \\
\hline & & \multirow{2}{*}{$\begin{array}{c}0 \\
\ln X\end{array}$} & \multicolumn{2}{|r|}{24} & \multicolumn{2}{|r|}{48} & \multicolumn{2}{|r|}{72} \\
\hline & & & $\ln X$ & $\mathrm{GM}^{*}, \mu$ & $\ln X$ & $\mathrm{GM}, \mu$ & $\ln X$ & $\mathrm{GM}, \mu$ \\
\hline Control & & 12.21 & 20.11 & $0.33 \pm 0.01$ & 20.72 & $0.18 \pm 0.02$ & 20.99 & $0.12 \pm 0.01$ \\
\hline \multirow{3}{*}{ Basil } & 0.1 & 12.21 & 19.87 & $0.32 \pm 0.02$ & 20.52 & $0.17 \pm 0.01$ & 19.30 & $0.10 \pm 0.01$ \\
\hline & 0.2 & 12.21 & 19.76 & $0.31 \pm 0.01$ & 19.24 & $0.15 \pm 0.02$ & 19.03 & $0.09 \pm 0.01$ \\
\hline & 0.3 & 12.21 & 10.82 & $0.32 \pm 0.01$ & 18.87 & $0.14 \pm 0.01$ & 18.40 & $0.09 \pm 0.01$ \\
\hline \multirow{3}{*}{ Thyme } & 0.1 & 12.21 & 19.20 & $0.29 \pm 0.01$ & 20.55 & $0.17 \pm 0.01$ & 19.37 & $0.10 \pm 0.01$ \\
\hline & 0.2 & 12.21 & 19.23 & $0.29 \pm 0.01$ & 20.44 & $0.17 \pm 0.01$ & 18.79 & $0.09 \pm 0.01$ \\
\hline & 0.3 & 12.21 & 19.04 & $0.28 \pm 0.02$ & 19.03 & $0.14 \pm 0.02$ & 17.18 & $0.07 \pm 0.01$ \\
\hline \multirow{3}{*}{ Tarragon } & 0.1 & 12.21 & 19.71 & $0.31 \pm 0.01$ & 20.70 & $0.18 \pm 0.01$ & 20.18 & $0.11 \pm 0.01$ \\
\hline & 0.2 & 12.21 & 19.46 & $0.30 \pm 0.02$ & 20.51 & $0.17 \pm 0.01$ & 19.80 & $0.11 \pm 0.01$ \\
\hline & 0.3 & 12.21 & 19.15 & $0.29 \pm 0.01$ & 19.26 & $0.15 \pm 0.01$ & 17.69 & $0.08 \pm 0.01$ \\
\hline
\end{tabular}

${ }^{\star}$ Note: GM-Growth Monitoring. 


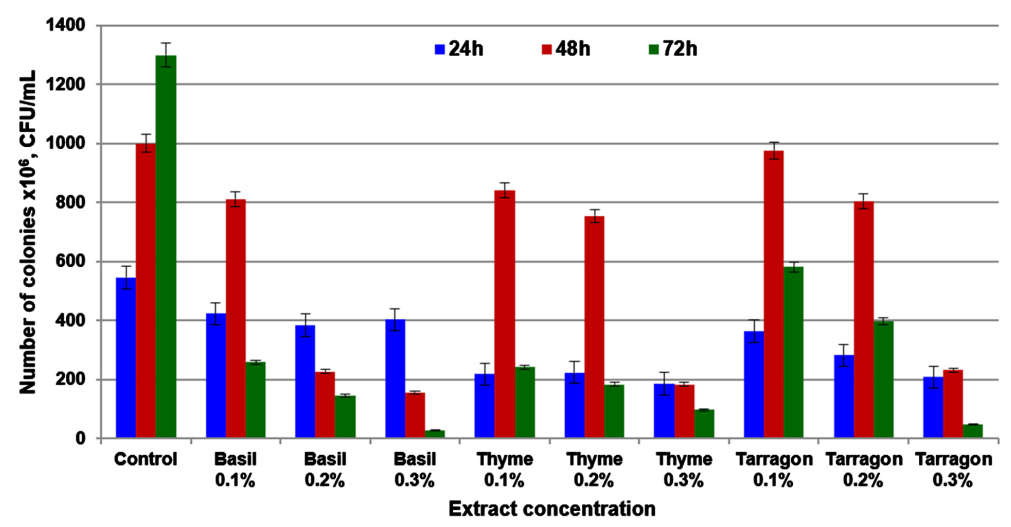

Figure 1. The impact of the addition of different concentrations of basil, thyme, and tarragon extracts on the growth of Salmonella Abony after 24, 48 and 72 hours (errors bars represent the standard deviation of three determinations).

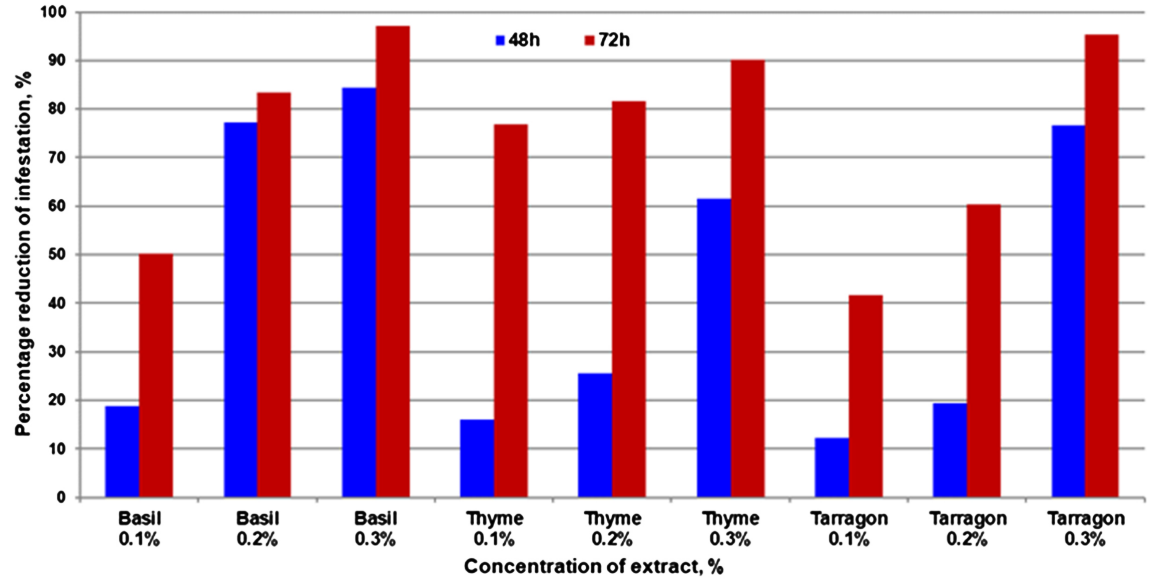

Figure 2. Percentage decrease in Salmonella Abony growth under the influence of basil, thyme, and tarragon extracts after 48 and 72 hours.

those with an addition of $0.3 \%$ the decrease in infestation was $84.4 \%$. Approximately these values were also maintained in the samples with the addition of $0.3 \%$ tarragon $(76.7 \%)$ and thyme (61.6\%).

Analyzing the case study data after 72 hours, it was found that Basil showed the highest rate of stopping the growth of $S$. abony (97\%) although at the concentration of $0.1 \%$, the reduction rate was the average one (50.3\%). The rate of decrease given by Tarragon was $95 \%$ (an average value among the samples of plants examined), although at concentration of $0.1 \%$, the effect was the smallest (41.7\%). Thyme showed the smallest decrease $(90.2 \%)$, while at the concentration of $0.1 \%$, the decrease was the highest (76.8\%). Probably, the results were influenced by the chemical composition of the studied plants. Based on the bibliographic study we can see that the composition of plants is quite complex, it depends on several factors including climatic and regional.

The interdependence between the percentage reduction of Salmonella Abony infestation and the concentrations of basil, thyme and tarragon extracts is shown in Figures 3-5. 


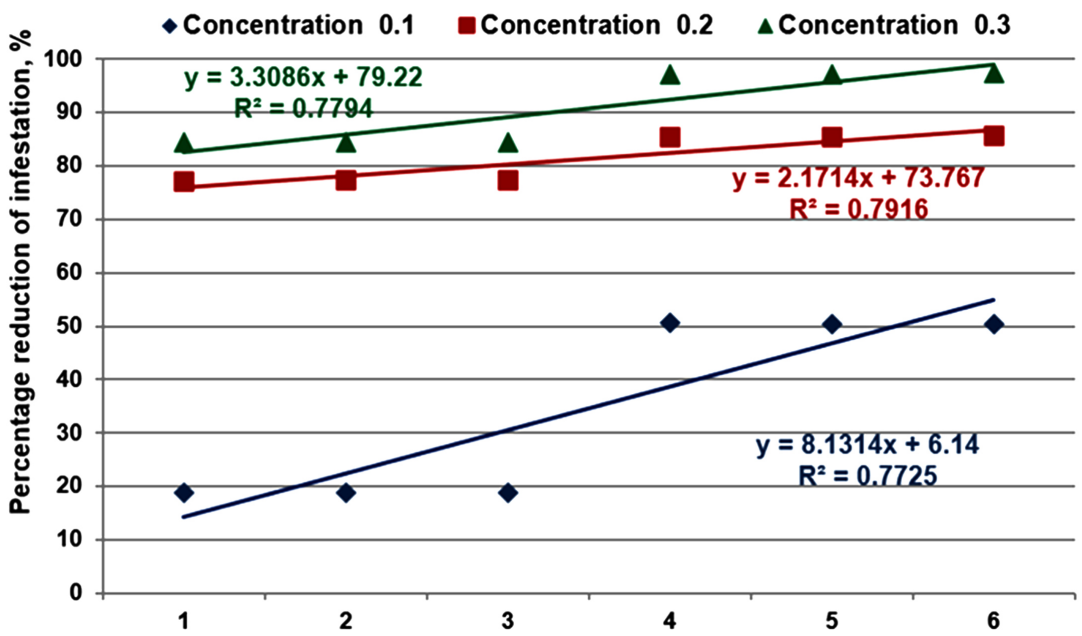

Figure 3. Interdependence between the percentage reduction of Salmonella Abony infestation and concentrations of basil extract.

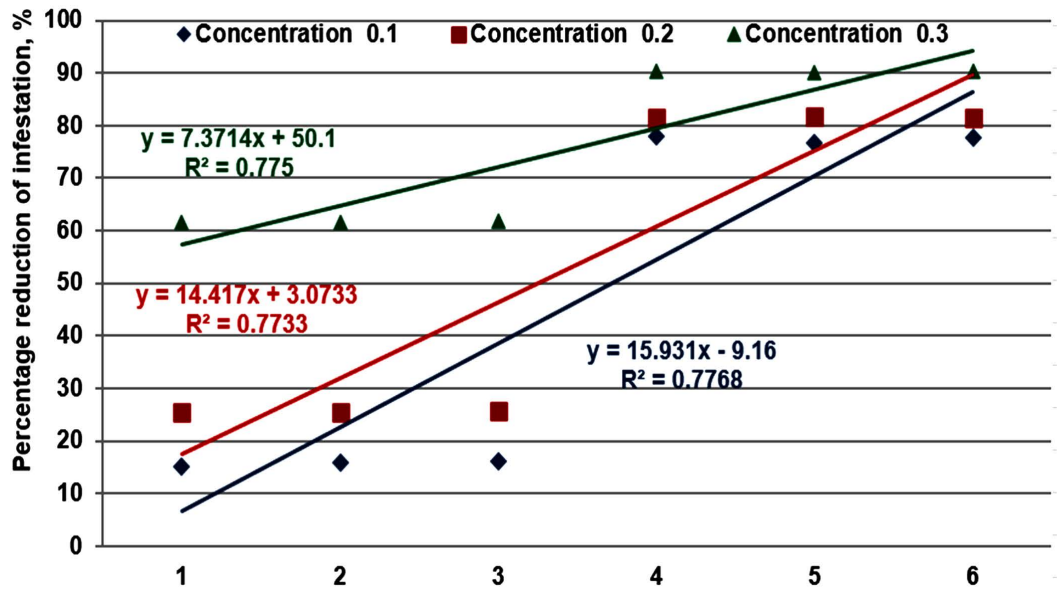

Figure 4. Interdependence between the percentage reduction of Salmonella Abony infestation and concentrations of thyme extract.

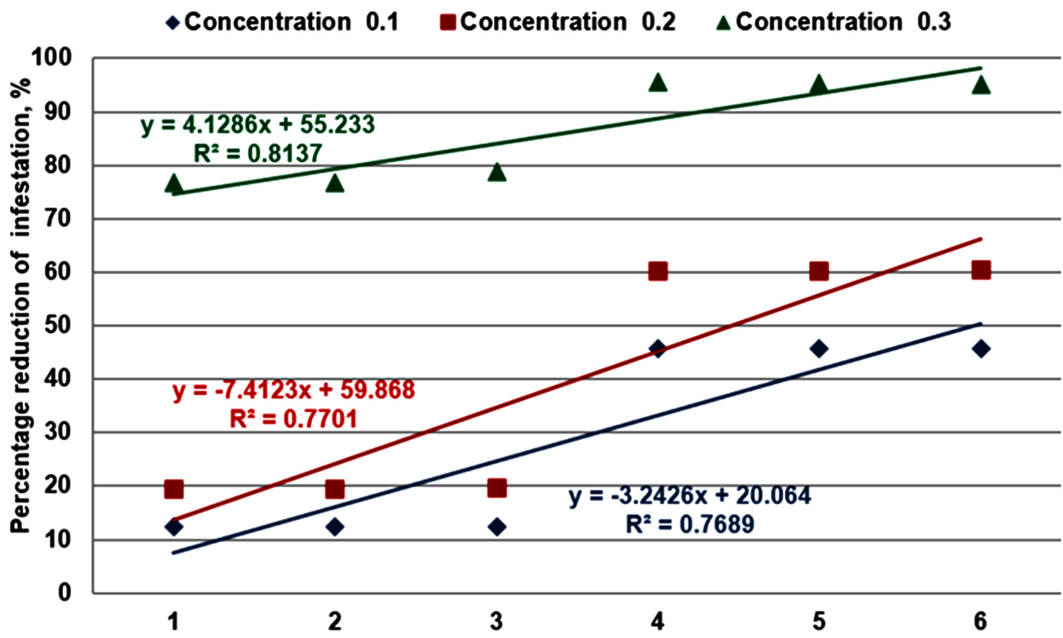

Figure 5. Interdependence between the percentage reduction of Salmonella Abony infestation and concentrations of tarragon extract. 
The results in Figures 3-5 show that the interdependence between the percentage reduction of Salmonella Abony infestation and the concentrations of basil, thyme and tarragon extracts was good.

\section{Conclusion}

Basil, thyme, tarragon have relevant antioxidant and antimicrobial properties. They are used as ingredients in products to control the infestation with pathogenic microorganisms. Reduction of Salmonella Abony infestation in sausage was $62 \%-84 \%$. The interdependence between the percentage reduction of Salmonella Abony infestation and the concentration of basil, thyme and tarragon was good: basil $\left(R^{2}=0.7725 \ldots 0.7916\right)$, thyme $\left(R^{2}=0.7733 \ldots 0.7768\right)$, tarragon $\left(\mathrm{R}^{2}=0.7689 \ldots 0.8137\right)$. All plants showed the same antimicrobial effect on Salmonella Abony.

\section{Acknowledgements}

This work was funded through Moldova State Project no. 20.80009.5107.09 "Improvement of food quality and safety by biotechnology and food engineering" running at the Technical University of Moldova.

\section{Conflicts of Interest}

The authors declare no conflicts of interest regarding the publication of this paper.

\section{References}

[1] Nieto, G. (2020) A Review on Applications and Uses of Thymus in the Food Industry. Plants, 9, 961. https://doi.org/10.3390/plants9080961

[2] Sauceda, E.N.R. (2011) Uso de Agentes Antimicrobianos Naturales en la Conservación de Frutas y Hortalizas. Ra Ximhai, 7, 153-170. https://doi.org/10.35197/rx.07.01.2011.14.er

[3] Burt, S. (2004) Essential Oils: Their Antibacterial Properties and Potential Applications in Foods-A Review. International Journal of Food Microbiology, 94, 223-253. https://doi.org/10.1016/j.ijfoodmicro.2004.03.022

[4] Kaloustian, J., Chevalier, J., Mikail, C., Martino, M., Abou, L. and Vergnes, M.-F. (2008) Étude de Six Huiles Essentielles: Composition Chimique et Activité Antibactérienne. Phytotherapie, 6, 160-164. https://doi.org/10.1007/s10298-008-0307-1

[5] Boggia, R., Zunin, P. and Turrini, F. (2020) Functional Foods and Food Supplements. Applied Sciences, 10, 8538. https://doi.org/10.3390/app10238538

[6] Sakkas, H. and Papadopoulou, C. (2017) Antimicrobial Activity of Basil, Oregano, and Thyme Essential Oils. Journal of Microbiolog and Biotechnology, 27, 429-438. https://doi.org/10.4014/jmb.1608.08024

[7] Gottardi, D., Bukvicki, D., Prasad, S. and Tyagi, A.K. (2016) Beneficial Effects of Spices in Food Preservation and Safety. Frontiers in Microbiology, 7, 1394. https://doi.org/10.3389/fmicb.2016.01394

[8] Alakomi, H.L., Maukonen, J., Honkapää, K., Storgårds, E., Quirin, K.W., Yang, B. and Saarela, M. (2017) Effect of Plant Antimicrobial Agents Containing Marinades 
on Storage Stability and Microbiological Quality of Broiler Chicken Cuts Packed with Modified Atmosphere Packaging. Journal of Food Protection, 80, 1689-1696. https://doi.org/10.4315/0362-028X.JFP-17-076

[9] Harpaz, S., Glatman, L., Drabkin, V. and Gelman, A. (2003) Effects of Herbal Essential Oils Used To Extend the Shelf Life of Freshwater-Reared Asian Sea Bass Fish (Lates calcarifer). Journal of Food Protection, 66, 410-417. https://doi.org/10.4315/0362-028X-66.3.410

[10] Skandamis, P.N., Tsigarida, E. and Nychas, G.J.E. (2002) The Effect of Oregano Essential Oil on Survival/Death of Salmonella typhimurium in Meat Stored at $5^{\circ} \mathrm{C}$ under Aerobic, VP/MAP Conditions. Food Microbiology, 19, 97-103.

https://doi.org/10.1006/fmic.2001.0447

[11] Solomakos, N., Govaris, A., Koidis, P. and Botsoglou, N. (2008) The Antimicrobial Effect of Thyme Essential Oil, Nisin, and Their Combination against Listeria monocytogenes in Minced Beef during Refrigerated Storage. Food Microbiology, 25, 120-127. https://doi.org/10.1016/j.fm.2007.07.002

[12] Tanabe, H., Yoshida, M. and Tomita, N. (2002) Comparison of the Antioxidant Activities of 22 Commonly Used Culinary Herbs and Spices on the Lipid Oxidation of Pork Meat. Animal Science Journal, 73, 389-393. https://doi.org/10.1046/j.1344-3941.2002.00054.x

[13] Medina, R., Dupertuis, L., Amadio, C., Dip, G., Zimmermann, M., Espejo, C. and Raimondo, E. (2003) Aceite Esencial de Tomillo Como Antioxidante y Conservador de Hamburguesas Funcionales. Revista de la Facultad de Ciencias Agrarias, 35, 13-23.

[14] Garcia, J., Albeiro, J., Falco, V., Franqueza, M.J. and Patarata, L. (2016) Chemical Characterization and Antimicrobial Properties of Herbs and Spices Essential Oils against Pathogens and Spoilage Bacteria Associated to Dry-Cured Meat Products. Journal of Essential Oil Research, 29, 117-125. https://doi.org/10.1080/10412905.2016.1212738

[15] Laranjo, M., Fernández-Léon, A.M., Potes, M.E., Agulheiro-Santos, A.C. and Elias, M. (2017) Use of Essential Oils in Food Preservation. In: Méndez-Vilas, A., Ed., Antimicrobial Research: Novel Bioknowledge and Educational Programs, Formatex Research Center, Badajoz, Spain, 177-188.

[16] Guerra-Rosas, M.I., Morales-Castro, J., Cubero-Márquez, M.A., Salvia-Trujillo, L. and Martín-Belloso, O. (2017) Antimicrobial Activity of Nanoemulsions Containing Essential Oils and High Methoxyl Pectin during Long-Term Storage. Food Control, 77, 131-138. https://doi.org/10.1016/j.foodcont.2017.02.008

[17] Amorati, R., Foti, M.C. and Valgimigli, L. (2013) Antioxidant Activity of Essential Oils. Journal of Agricultural and Food Chemistry, 61, 10835-10847.

https://doi.org/10.1021/jf403496k

[18] Kumar, Y., Yadav, D.N., Ahmad, T. and Narsaiah, K. (2015) Recent Trends in the Use of Natural Antioxidants for Meat and Meat Products. Comprehensive Reviews in Food Science and Food Safety, 14, 796-812. https://doi.org/10.1111/1541-4337.12156

[19] Viuda-Martos, M., Ruiz-Navajas, Y., Fernández-López, J. and Pérez-Álvarez, J.A. (2010) Effect of Orange Dietary Fibre, Oregano Essential Oil and Packaging Conditions on Shelf-Life of Bologna Sausages. Food Control, 21, 436-443.

https://doi.org/10.1016/j.foodcont.2009.07.004

[20] Mohamed, H.M.H. and Mansour, H.A. (2012) Incorporating Essential Oils of Marjoram and Rosemary in the Formulation of Beef Patties Manufactured with Mechanically Deboned Poultry Meat to Improve the Lipid Stability and Sensory Attributes. 
LWT-Food Science and Technology, 45, 79-87. https://doi.org/10.1016/j.lwt.2011.07.031

[21] Maqsood, S., Benjakul, S., Abushelaibi, A. and Alam, A. (2014) Phenolic Compounds and Plant Phenolic Extracts as Natural Antioxidants in Prevention of Lipid Oxidation in Seafood. Comprehensive Reviews in Food Science and Food Safety, 13, 1125-1140. https://doi.org/10.1111/1541-4337.12106

[22] Fernández-León, M.F., Fernández-León, A.M., Lozano, M., Ayuso, M.C. and González-Gómez, D. (2012) Identification, Quantification and Comparison of the Principal Bioactive Compounds and External Quality Parameters of Two Broccoli Cultivars. Journal of Functional Foods, 4, 465-473.

https://doi.org/10.1016/j.jff.2012.02.005

[23] Bolling, B., Dolnikowski, G., Blumberg, J. and Chen, C.Y. (2010) Polyphenol Content and Antioxidant Activity of California Almonds Depend on Cultivar and Harvest Year. Food Chemistry, 122, 819-825.

https://doi.org/10.1016/j.foodchem.2010.03.068

[24] Jaworska, D., Rosiak, E., Kostyra, E., Jaszczyk, K., Wroniszewska, M. and Przybylski, W. (2021) Effect of Herbal Addition on the Microbiological, Oxidative Stability and Sensory Quality of Minced Poultry Meat. Foods, 10, 1537.

https://doi.org/10.3390/foods10071537

[25] Tekippe, J.A., Hristov, A.N., Heyler, K.S., Cassidy, T.W., Zheljazkov, V.D., Ferreira, J.F.S., Karnati, S.K. and Varga, G.A. (2011) Rumen Fermentation and Production Effects of Origanum vulgare L. Leaves in Lactating Dairy Cows. Journal Dairy Science, 94, 5065-5079. https://doi.org/10.3168/jds.2010-4095

[26] Van Haute, S., Raes, K., Van der Meeren, P. and Sampers, I. (2016) The Effect of Cinnamon, Oregano and Thyme Essential Oils in Marinade on the Microbial Shelf Life of Fish and Meat Products. Food Control, 68, 30-39.

https://doi.org/10.1016/j.foodcont.2016.03.025

[27] Wanasundara, U.N. and Shahidi, F. (1996) Stabilization of Seal Blubber and Menhaden Oils with Green Tea Catechins. Journal of the American Oil Chemists Society, 73, 1183-1190. https://doi.org/10.1007/BF02523382

[28] Rota, C., Herrera, A., Martinez, R.M., Sotomayor, J.A. and Jordán, M.J. (2008) Antimicrobial Activity and Chemical Composition of Thymus vulgaris, Thymus zygis and Thymus hyemalis Essential Oils. Food Control, 19, 681-687.

https://doi.org/10.1016/j.foodcont.2007.07.007

[29] Hashmi, L.S., Hossain, M.A., Weli, A.M., Al-Riyami, Q. and Al-Sabahi, J.N. (2013) Gas Chromatography-Mass Spectrometry Analysis of Different Organic Crude Extracts from the Local Medicinal Plant of Thymus vulgaris L. Asian Pacific Journal of Tropical Biomedicine, 3, 69-73. https://doi.org/10.1016/S2221-1691(13)60026-X

[30] Tepe, B., Sökmen, M., Akpulat, H.A., Daferera, D., Polissiou, M. and Sokmen, A. (2005) Antioxidative Activity of the Essential Oils of Thymus sipyleus subsp. sipyleus var. sipyleus and Thymus sipyleus subsp. sipyleus var. rosulans. Journal of Food Engineering, 66, 447-454. https://doi.org/10.1016/j.jfoodeng.2004.04.015

[31] Dorman, H., Peltoketo, A., Hiltunen, R. and Tikkanen, M. (2003) Characterisation of the Antioxidant Properties of De-Odourised Aqueous Extracts from Selected Lamiaceae Herbs. Food Chemistry, 83, 255-262. https://doi.org/10.1016/S0308-8146(03)00088-8

[32] Soare, J.R., Dinis, T.C.P., Cunha, A.P. and Almeida, L.M. (1997) Antioxidant Activities of Some Extracts of Thymus zygis. Free Radical Research, 26, 469-478. https://doi.org/10.3109/10715769709084484 
[33] Yu, Y.-M., Chao, T.-Y., Chang, W.-C., Chang, M.J. and Lee, M.-F. (2016) Thymol Reduces Oxidative Stress, Aortic Intimal Thickening, and Inflammation-Related Gene Expression in Hyperlipidemic Rabbits. Journal of Food and Drug Analysis, 24, 556-563. https://doi.org/10.1016/j.jfda.2016.02.004

[34] Chouhan, S., Sharma, K. and Guleria, S. (2017) Antimicrobial Activity of Some Essential Oils-Present Status and Future Perspectives. Medicines, 4, 58. https://doi.org/10.3390/medicines4030058

[35] Juven, B., Kanner, J., Schved, F. and Weisslowicz, H. (1994) Factors That Interact with the Antibacterial Action of Thyme Essential Oil and Its Active Constituents. Journal of Applied Bacteriology, 76, 626-631. https://doi.org/10.1111/j.1365-2672.1994.tb01661.x

[36] Evans, J.D. and Martin, S.A. (2000) Effects of Thymol on Ruminal Microorganisms. Current Microbiology, 41, 336-340. https://doi.org/10.1007/s002840010145

[37] Falowo, A.B., Mukumbo, F.E., Idamokoro, E.M., Afolayan, A.J. and Muchenje, V. (2019) Phytochemical Constituents and Antioxidant Activity of Sweet Basil (Ocimum basilicum L.) Essential Oil on Ground Beef from Boran and Nguni Cattle. International Journal of Food Science, 2019, Article ID: 2628747. https://doi.org/10.1155/2019/2628747

[38] Marwat, S.K., Khan, M.S., Ghulam, S., Anwar, N., Mustafa, G. and Usman, K. (2011) Phytochemical Constituents and Pharmacological Activities of Sweet BasilOcimum basilicum L. (Lamiaceae). Asian Journal of Chemistry, 23, 3773-3782.

[39] Taie, H.A.A., Salama, Z.A.-E.R. and Radwan, S. (2010) Potential Activity of Basil Plants as a Source of Antioxidants and Anticancer Agents as Affected by Organic and Bio-Organic Fertilization. Notulae Botanicae Horti Agrobotanici Cluj-Napoca, 38, 119-127.

[40] Suppakul, P., Miltz, J., Sonneveld, K. and Bigger, S.W. (2003) Antimicrobial Properties of Basil and Its Possible Application in Food Packaging. Journal of Agricultural and Food Chemistry, 51, 3197-3207. https://doi.org/10.1021/jf021038t

[41] Zheljazkov, V.D., Cantrell, C.L., Tekwani, B. and Khan, S.I. (2008) Content, Composition, and Bioactivity of the Essential Oils of Three Basil Genotypes as a Function of Harvesting. Journal of Agricultural and Food Chemistry, 56, 380-385. https://doi.org/10.1021/jf0725629

[42] Zheljazkov, V.D., Callahan, A. and Cantrell, C.L. (2008) Yield and Oil Composition of 38 Basil (Ocimum basilicum L.) Accessions Grown in Mississippi. Journal of Agricultural and Food Chemistry, 56, 241-245. https://doi.org/10.1021/jf072447y

[43] Rezzoug, M., Bakchiche, B., Gherib, A., Roberta, A., Guido, F., Kilinçarslan, Ö., Mammadov, R. and Bardaweel, S.K. (2019) Chemical Composition and Bioactivity of Essential Oils and Ethanolic Extracts of Ocimum basilicum L. and Thymus algeriensis Boiss. \& Reut. from the Algerian Saharan Atlas. BMC Complementary and Alternative Medicine, 19, Article No. 146. https://doi.org/10.1186/s12906-019-2556-y

[44] Tiwari, B.K., Valdramidis, V.P., O’Donnell, C.P., Muthukumarappan, K., Bourke, P. and Cullen, P.J. (2009) Application of Natural Antimicrobials for Food Preservation. Journal of Agricultural and Food Chemistry, 57, 5987-6000. https://doi.org/10.1021/jf900668n

[45] Cruz, L.R.O., Polyzos, N., Fernandes, Â., Petropoulos, S.A., Gioia, F.D., Dias, M.I., Pinela, J., Kostić, M., Soković, M., Ferreira, I.C.F.R. and Barros, L. (2020) Effect of Saline Conditions on Chemical Profile and the Bioactive Properties of Three RedColored Basil Cultivars. Agronomy, 10, 1824. 
https://doi.org/10.3390/agronomy10111824

[46] Güez, C.M., Souza, R.O., Fischer, P., Leão, M.F.M., Duarte, J.A., Boligon, A.A., Athayde, M.L., Zuravski, L., Oliveira, L.F.S. and Machado, M.M. (2017) Evaluation of Basil Extract (Ocimum basilicum L.) on Oxidative, Antigenotoxic and Anti-Inflammatory Effects in Human Leukocytes Cell Cultures Exposed to Challenging Agents. Brazilian Journal of Pharmaceutical Sciences, 53, e15098. https://doi.org/10.1590/s2175-97902017000115098

[47] Syafiq, R., Sapuan, S.M., Zuhri, M.Y.M., Ilyas, R.A., Nazrin, A., Sherwani, S.F.K. and Khalina, A. (2020) Antimicrobial Activities of Starch-Based Biopolymers and Biocomposites Incorporated with Plant Essential Oils: A Review. Polymers, 12, 2403. https://doi.org/10.3390/polym12102403

[48] Abou El-Soud, N.H., Deabes, M., El-Kassem, L.A. and Khalil, M. (2015) Chemical Composition and Antifungal Activity of Ocimum basilicum L. Essential Oil. Journal of Medical Sciences, 3, 374-379. https://doi.org/10.3889/oamjms.2015.082

[49] Ökmen, G. and Balpinar, N. (2018) Antibacterial and Antioxidant Activities of Ocimum basilicum L. against Mastitis Pathogens. Cumhuriyet Science Journal, 39, 573-580. https://doi.org/10.17776/csj.409675

[50] Alsaiqali, M., El-Shibiny, A.A., Adel, M., Abdel-Samie, M.A.S. and Ghoneim, S. (2016) Use of Some Essential Oils as Antimicrobial Agents to Control Pathogenic Bacteria in Beef Burger. World Journal of Dairy \& Food Sciences, 11, 109-120.

[51] Tatarov, P. (2017) Chimia Produselor Alimentare. Ed. Tehnica-Info, UTM, 450. (In Romanian)

[52] Salem, A.M., Amin, R.A. and Afifi, G.S.A. (2010) Studies on Antimicrobial and antioxidant Efficiency of Some Essential Oils in Minced Beef. Journal of American Science, 6, 691-700.

[53] Chaleshtoria, S.R., Roknib, N., Rafieian-Kopaeic, M., Dreesd, F., Sharafati-Chaleshtoric, A. and Salehic, E. (2014) Use of Tarragon (Artemisia dracunculus) Essential Oil as a Natural Preservative in Beef Burger. Italian Journal of Food Science, 26, 427-432.

[54] Behbahani, B.A., Shahidi, F., Yazdi, F.T., Mortazavi, S.A. and Mohebbi, M. (2017) Antioxidant Activity and Antimicrobial Effect of Tarragon (Artemisia dracunculus) Extract and Chemical Composition of its Essential Oil. Journal of Food Measurement and Characterization, 11, 847-863.

https://doi.org/10.1007/s11694-016-9456-3

[55] Abdollahnejad, F., Kobarfard, F., Kamalinejad, M., Mehrgan, H. and Babaeian, M. (2016) Yield, Chemical Composition and Antibacterial Activity of Artemisia dracunculus L. Essential Oils Obtained by Two Different Methods. Journal of Essential Oil Bearing Plants, 19, 574-581.

https://doi.org/10.1080/0972060X.2014.963167

[56] Tajbakhsh, M. and Soleimani, N. (2018) Evaluation of the Bactericidal Effects of Zingiber officinale, Aloysia citrodora and Artemisia dracunculus on the Survival of Standard Gram-Positive and Gram-Negative Bacterial Strains. Jorjani Biomedicine Journal, 6, 22-32. https://doi.org/10.29252/jorjanibiomedj.6.1.22

[57] Socaciu, M.-I., Fogarasi, M., Semeniuc, C.A., Socaci, S.A., Rotar, M.A., Mureşan, V., Pop, O.L. and Vodnar, D.C. (2020) Formulation and Characterization of Antimicrobial Edible Films Based on Whey Protein Isolate and Tarragon Essential Oil. Polymers, 12, 1748. https://doi.org/10.3390/polym12081748

[58] Ribeiro, A., Barros, L., Calhelh, R.C., Carocho, M., Ćirić, A., Sokovic, M., Dias, M.M., Santos-Buelga, C., Barreiro, M.F. and Ferreira, I.C.F.R. (2016) Tarragon Phenolic Extract as a Functional Ingredient for Pizza Dough: Comparative Performance 
with Ascorbic Acid (E300). Journal of Functional Foods, 26, 268-278. https://doi.org/10.1016/j.jff.2016.08.019

[59] Zarezade, V., Moludi, J., Mostafazadeh, M., Mohammadi, M. and Veisi, A. (2018) Antioxidant and Hepatoprotective Effects of Artemisia dracunculus against CCl4Induced Hepatotoxicity in Rats. Avicenna Journal of Phytomedicine, 8, 51-62.

[60] Majdan, M., Kiss, A.K., Hałasa, R., Granica, S., Osińska, E. and Czerwińska, M.E. (2020) Inhibition of Neutrophil Functions and Antibacterial Effects of Tarragon ( $A r$ temisia dracunculus L.) Infusion-Phytochemical Characterization. Frontiers in Pharmacology, 11, 947. https://doi.org/10.3389/fphar.2020.00947

[61] Karabagias, I., Badeka, A. and Kontominas, M.G. (2011) Shelf Life Extension of Lamb Meat Using Thyme or Oregano Essential Oils and Modified Atmosphere Packaging. Meat Science, 88, 109-116. https://doi.org/10.1016/j.meatsci.2010.12.010

[62] Lens-Lisbonne, C., Cremieux, A., Maillard, C. and Balansard, G. (1987) Methodes d'evaluation de l'activite antibacterienne des huiles essentielles: Application aux essences de Thym et de cannelle. Journal de Pharmacie de Belgique, 42, 297-302.

[63] De Martino, L., Bruno, M., Formisano, C., De Feo, V., Napolitano, F., Rosselli, S. and Senatore, F. (2009) Chemical Composition and Antimicrobial Activity of the Essential Oils from Two Species of Thymus Growing Wild in Southern Italy. Molecules, 14, 4614-4624. https://doi.org/10.3390/molecules14114614

[64] McGimpsey, J.A., Douglas, M.H, Van Klink, J.W., Beauregard, D.A. and Perry, N.B. (1994) Seasonal Variation in Essential Oil Yield and Composition from Naturalized Thymus vulgaris L. in New Zealand. Flavour and Fragrance Journal, 9, 347-52. https://doi.org/10.1002/ffj.2730090613

[65] Cosentino, S., Tuberoso, C.I.G., Pisano, B., Satta, M., Mascia, V., Arzedi, E. and Palmas, F. (1999) In-Vitro Antimicrobial Activity and Chemical Composition of Sardinian Thymus Essential Oils. Letters in Applied Microbiology, 29, 130-135. https://doi.org/10.1046/j.1472-765X.1999.00605.x

[66] Marino, M., Bersani, C. and Comi, G. (1999) Antimicrobial Activity of the Essential Oils of Thymus vulgaris L. Measured Using a Bioimpedometric Method. Journal of Food Protection, 62, 1017-1023. https://doi.org/10.4315/0362-028X-62.9.1017

[67] Juliano, C., Mattana, A. and Usai, M. (2000) Composition and in Vitro Antimicrobial Activity of the Essential Oil of Thymus herba-barona Loisel Growing Wild in Sardinia. Journal of Essential Oil Research, 12, 516-522. https://doi.org/10.1080/10412905.2000.9699578

[68] Fratianni, F., De Martino, L., Melone, A., De Feo, V., Coppola, R. and Nazzaro, F. (2010) Preservation of Chicken Breast Meat Treated with Thyme and Balm Essential Oils. Journal of Food Science, 75, 528-535. https://doi.org/10.1111/j.1750-3841.2010.01791.x

[69] Turgis, M., Vu, K.D., Dupont, C. and Lacroix, M. (2012) Combined Antimicrobial Effect of Essential Oils and Bacteriocins against Foodborne Pathogens and Food Spoilage Bacteria. Food Research International, 48, 696-702.

https://doi.org/10.1016/j.foodres.2012.06.016

[70] Aljabeili, H.S., Barakat, H. and Abdel-Rahman, H.A. (2018) Chemical Composition, Antibacterial and Antioxidant Activities of Thyme Essential Oil (Thymus vulgaris). Food and Nutrition Sciences, 9, 433-446. https://doi.org/10.4236/fns.2018.95034

[71] Ballester-Costa, C., Sendra, E., Fernández-López, J., Pérez-Álvarez, J.A. and ViudaMartos, M. (2013) Chemical Composition and in Vitro Antibacterial Properties of Essential Oils of Four Thymus Species from Organic Growth. Industrial Crops and Products, 50, 304-311. https://doi.org/10.1016/j.indcrop.2013.07.052 
[72] Alsaraf, S., Hadi, Z., Al-Lawati, W.M., Al Lawati, A.A. and Khan, S.A. (2020) Chemical Composition, in Vitro Antibacterial and Antioxidant Potential of Omani Thyme Essential Oil along with in Silico Studies of Its Major Constituent. Journal of King Saud University-Science, 32, 1021-1028. https://doi.org/10.1016/j.jksus.2019.09.006

[73] Hosni, K., Hassen, I., Chaâbane, H., Jemli, M., Dallali, S., Sebei, H. and Casabianca, H. (2013) Enzyme-Assisted Extraction of Essential Oils from Thyme (Thymus capitatus L.) and Rosemary (Rosmarinus officinalis L.): Impact on Yield, Chemical Composition and Antimicrobial Activity. Industrial Crops and Products, 47, 291-299. https://doi.org/10.1016/j.indcrop.2013.03.023

[74] Al Abbasy, D.W., Pathare, N., Al-Sabahi, J.N. and Khan, S.A. (2015) Chemical Composition and Antibacterial Activity of Essential Oil Isolated from Omani Basil (Ocimum basilicum Linn.). Asian Pacific Journal of Tropical Disease, 5, 645-649. https://doi.org/10.1016/S2222-1808(15)60905-7

[75] Amzad Hossain, M., Kabir, M.J., Mizanur Rahman, S.M., Das, A.K., Singha, S.K., Alam, Md.K. and Rahman, A. (2010) Antibacterial Properties of Essential Oils and Methanol Extracts of Sweet Basil Ocimum basilicum Occurring in Bangladesh. Pharmaceutical Biology, 48, 504-511. https://doi.org/10.3109/13880200903190977

[76] Chenni, M., El Abed, D., Rakotomanomana, N., Fernandez, X. and Chemat, F. (2016) Comparative Study of Essential Oils Extracted from Egyptian Basil Leaves (Ocimum basilicum L.) Using Hydro-Distillation and Solvent-Free Microwave Extraction. Molecules, 21, 113. https://doi.org/10.3390/molecules21010113

[77] Amor, G., Sabbah, M., Caputo, L., Idbella, M., De Feo, V., Porta, R., Fechtali, T. and Mauriello, G. (2021) Basil Essential Oil: Composition, Antimicrobial Properties, and Microencapsulation to Produce Active Chitosan Films for Food Packaging. Foods, 10, 121. https://doi.org/10.3390/foods10010121

[78] Chaleshtori, R.S., Rokni, N., Razavilar, V. and Kopaei, M.R. (2013) The Evaluation of the Antibacterial and Antioxidant Activity of Tarragon (Artemisia dracunculus L.) Essential Oil and Its Chemical Composition. Jundishapur Journal of Microbiology, 6, e7877. https://doi.org/10.5812/jjm.7877

[79] Mumivand, H., Babalar, M., Tabrizi, L., Craker, L.E., Shokrpour, M. and Hadian, J. (2017) Antioxidant Properties and Principal Phenolic Phytochemicals of Iranian Tarragon (Artemisia dracunculus L.) Accessions. Horticulture, Environment, and Biotechnology, 58, 414-422. https://doi.org/10.1007/s13580-017-0121-5

[80] Deans, S.G. and Svoboda, K.P. (2015) Antibacterial Activity of French Tarragon (Artemisia dracunculus Linn.) Essential Oil and Its Constituents during Ontogeny. Journal of Horticultural Science, 63, 503-508. https://doi.org/10.1080/14620316.1988.11515884

[81] Reyes-Jurado, F., Franco-Vega, A., Ramírez-Corona, N., Palou, E. and López-Malo, A. (2014) Essential Oils: Antimicrobial Activities, Extraction Methods, and Their Modeling. Food Engineering Reviews, 7, 275-297. https://doi.org/10.1007/s12393-014-9099-2

[82] Lucia da Cruz Cabral, L., Fernandez Pinto, V. and Patriarca, A. (2013) Application of Plant Derived Compounds to Control Fungal Spoilage and Mycotoxin Production in Foods. International Journal of Food Microbiology, 166, 1-14. https://doi.org/10.1016/j.ijfoodmicro.2013.05.026

[83] Nzeako, B.C., Al-Kharousi, Z.S.N. and Al-Mahrooqui, Z. (2006) Antimicrobial Activities of Clove and Thyme Extracts. Sultan Qaboos University Medical Journal, 6, 33-39.

[84] Silva-Angulo, A.B., Zanini, S.F., Rosenthal, A., Rodrigo, D., Klein, G. and Martínez, 
A. (2015) Comparative Study of the Effects of Citral on the Growth and Injury of Listeria innocua and Listeria monocytogenes Cells. PLoS ONE, 10, e0114026.

https://doi.org/10.1371/journal.pone.0114026

[85] Ekiert, H., Świątkowska, J., Knut, E., Klin, P., Rzepiela, A., Tomczyk, M. and Szopa, A. (2021) Artemisia dracunculus (Tarragon): A Review of Its Traditional Uses, Phytochemistry and Pharmacology. Frontiers in Pharmacology, 12, Article ID: 653993. https://doi.org/10.3389/fphar.2021.653993

[86] ISO 6579-1:2017. Microbiology of the Food Chain-Horizontal Method for the Detection, Enumeration and Serotyping of Salmonella-Part 1: Detection of Salmonella spp. 